\title{
ВПРОВАДЖЕННЯ У ПРОЦЕС НАВЧАННЯ ФАХІВЦІВ ПЕРВИННОЇ ЛАНКИ МЕДИЧНОЇ ДОПОМОГИ ВОЛИНСЬКОЇ ОБЛАСТІ СУЧАСНИХ ЗНАНЬ 3 ІНТЕГРОВАНОГО ВЕДЕННЯ ВИПАДКІВ ГІПЕРТЕНЗІЇ ТА ЦУКРОВОГО ДІАБЕТУ
}

\author{
${ }^{1}$ Львівський національний медичний університет імені Данила Галицького, м. Львів, Україна \\ Центр громадського здоров'я МОЗ України, м. Київ, Україна
}

\begin{abstract}
Мета: проаналізувати можливості організації навчання фрахівців первинної медичної допомоги Волинської області з питань профілактики неінфекційних захворювань та інтегрованого ведення пацієнтів із гіпертензією та цукровим діабетом.

Матеріали і методи. У роботі використано комплекс специфічних методів досліджень соціальної медицини, а також наукової педагогіки: системного підходу та системного аналізу, медико-статистичний, моделювання, організаційного експерименту, контент-аналізу, інструментальний, емпіричний, навчально-дидактичний та наукового пізнання.

Результати. Дводенний навчальний курс «Інтегроване ведення випадків гіпертензії та діабету» розроблено національною групою експертів за технічної підтримки ВООЗ і запропоновано для подальшої імплементації в Україні. Цей курс $€$ оптимальним для підготовки фрахівців первинної медичної допомоги.

Методики тренінгу включають інтерактивні лекції, практичні заняття, розгляд клінічних випадків та відпрацювання практичних навичок. Обов'язковим $€$ оцінювання занять, тренерів, тренінгу в цілому. До навчально-методичних матеріалів входять мультимедійні презентації лекцій, роздаткові матеріали для кожного учасника тренінгу.

Водночас заплановано запровадити розроблені дистанційні курси з питань неіноекційних захворювань, за успішне проходження яких сімейні лікарі зможуть отримувати бали безперервного просресійного розвитку.

Висновки. Для забезпечення існування висококваліфікованої та якісної медичної допомоги необхідна наявність достатньої кількості професіоналів, навчених ії надавати. Ключову роль у системі профрілактики неінфекційних захворювань (зокрема гіпертензії та цукрового діабету) відіграють працівники, які працюють на первинній ланці медичної допомоги. Якщо вони пройдуть якісну підготовку з вищезазначених питань, існує реальна можливість того, що це матиме позитивний вплив на результати їхньої роботи з профілактики неінфекційних захворювань у пацієнтів.
\end{abstract}

КЛЮЧОВІ СЛОВА: неінфекційні захворювання; артеріальна гіпертензія; цукровий діабет; тренінг; ВоОз.

Якість послуг, які надають медичні працівники на рівні первинної медичної допомоги (ПМД), залежить від наявності у них спеціалізованих знань. Важливість якісної підготовки медичних кадрів складно переоцінити, а система профресійної підготовки лікарів та медичних сестер має здійснюватися відповідно до світових і загальноєвропейських стандартів.

Чільне місце у поглибленні знань з окремих вузьких проблем становить участь надавачів медичних послуг у короткотермінових тренінгах, суть яких полягає в організації занять 3 певних тем, які проводять спеціально підготовлені висококваліфріковані викладачі. Сама система підготовки зазначених викладачів теж є складним багатокомпонентним процесом і потребує спеціальних напрацювань.

На сьогодні домінуючим викликом для громадського здоров'я кожної 3 країн-членів Європейського регіону Всесвітньої організації охорони здоров'я (ВООЗ), включаючи й Україну, є неінфекційні захворювання (НІ3). В Україні, за офріційними статистичними даними Державної служби статистики України та Центру медичної статистики Міністерства охорони здоров'я України (МО3), протягом останніх 10 років смертність від НІ3 становить понад 80 \% у структурі загальної смертності. Показники смертності від серцевосудинних захворювань (ССЗ) в Україні $є$ одними 3 найвищих у Європі й досягають 772,1 смертей на 100 тис. серед чоловіків та 440,9 на 100 тис. серед жінок. Майже 30 \% чоловіків, які помирають від НI3, не досягли віку 60 років $[2,3,5]$.

3 метою запобігання та боротьби з НІЗ в Україні реалізовують два міжнародні проекти. Перший з них - «Неінфекційні захворювання: профрілактика та зміцнення здоров'я в Україні», був ініційований спільно із МО3 України і ВОО3 [6] за підтримки Швейцарської агенції розвитку та співробітництва (ШАPC/SDC) і тривав з травня 2015 
до травня 2019 рр. Загальною метою проекту було покращення благополуччя населення України шляхом зниження захворюваності та смертності, що пов'язані з НІ3, зокрема особливу увагу приділяли захворюваності та смертності, які пов'язані з серцево-судинними захворюваннями. Цей проект передбачав зниження рівня тяжкості HI3 в Україні та враховував рекомендації Глобального плану дій ВООЗ щодо профрілактики та боротьби з НІ3 на 2013-2020 рр., схваленого Резолюцією (WHA66.10) Всесвітньої асамблеї охорони здоров'я [9]. На сьогодні проект успішно реалізовано.

Відповідно до другого компонента цього проекту («Посилення профрілактики та боротьби із НІ3 у клінічних та громадських умовах»), була проведена підготовка понад 10 тис. працівників ПМД у 7-ми пілотних регіонах України щодо основних інтервенцій, які допоможуть здійснювати профрілактику, діагностику та лікування НІ3.

Другим міжнародним проектом, який впроваджують в Україні протягом 2015-2020 рр., є проект Світового банку «Поліпшення охорони здоров'я на службі у людей» [10], ініційований на запит Уряду України Міжнародним банком реконструкції та розвитку спільно з Міністерством охорони здоров'я України, Всесвітньою організацією охорони здоров'я, та державні органи, що реалізують політику охорони здоров'я у регіонах.

Діяльність цього проекту спрямована на досягнення наступних трьох пріоритетних завдань у системі охорони здоров'я: боротьба з неінфекційними захворюваннями 3 приділенням особливої уваги профілактиці; поліпшення якості та ефрективності медичної допомоги; оптимізація та реструктуризація лікарень і амбулаторних послуг вторинного рівня. У межах цього проекту передбачено проведення навчання фахівців ПМД із питань профрілактики НІЗ. Одним із навчальних курсів $€$ «Інтегроване ведення випадків гіпертензії та діабету». Передбачено його впровадження у навчальний процес на місцевому рівні у 8-ми відібраних на конкурсній основі регіонах, у тому числі у Волинській області.

Мета роботи: проаналізувати можливості організації навчання фрахівців ПМД Волинської області з питань профрілактики НІЗ та інтегрованого ведення пацієнтів із гіпертензією та цукровим діабетом.

Матеріали і методи. У роботі використано комплекс специфічних методів досліджень соціальної медицини, а також наукової педагогіки: системного підходу та системного аналізу, медико-статистичний, моделювання, організаційного експерименту, контент-аналізу, інструментальний, емпіричний, навчально-дидактичний та наукового пізнання.
Результати дослідження та їх обговорення. Начальний курс «Інтегроване ведення випадків гіпертензії та діабету» ґрунтується на документах ВОО3 щодо основних втручань із НI3 (WHO-PEN) для ПМД [8], рекомендаціях Європейського товариства кардіологів, а також національних клінічних рекомендаціях. Він був розроблений групою національних експертів за підтримки ВООЗ.

Методики тренінгу включають інтерактивні лекції, практичні заняття, розгляд клінічних випадків та відпрацювання практичних навичок. Обов'язковим $€$ оцінювання занять, тренерів, тренінгу в цілому. До навчально-методичних матеріалів входять мультимедійні презентації лекцій, роздаткові матеріали для кожного учасника тренінгу.

Цільовою аудиторією тренінгу є фрахівці (лікарі та медичні сестри), які працюють на рівні ПМд. Мета цього дводенного тренінгу - навчити цільову аудиторію інтегрованому веденню випадків артеріальної гіпертензії та цукрового діабету. Після проходження тренінгу срахівці ПМД повинні вміти виявляти та вести пацієнтів з артеріальною гіпертензією, цукровим діабетом та чинниками ризику НІЗ з урахуванням загального ризику розвитку серцево-судинних захворювань, проводити корекцію чинників ризику, мотиваційне консультування, впроваджувати базові практики вдосконалення якості.

Особливістю цього тренінгу $є$ нестандартна структура занять: протягом лекції передбачено групову роботу, яку проводять впродовж 3-5 хв або до 10 хв. Також $є$ обов'язковим обговорення питання в парах (2 хв) та надання відповіді на одне питання (3 хв). Наступним йде «мозковий штурм» у малих групах (наприклад 6 учасників) і підсумовування ключових моментів на фрліпчарті (5 хв). Завершується тренінг отриманням зворотного зв'язку від груп шляхом обговорення та анкетування учасників.

До основних практичних завдань для учасників тренінгу належать відпрацювання вмінь щодо:

- визначення пацієнтів із високим ризиком, які потребують первинної та вторинної профрілактики гіпертензії та цукрового діабету;

- вимірювання зросту і маси для розрахунку індексу маси тіла; окружності талії [1];

- вимірювання артеріального тиску та його оцінка [1];

- розрахунок ступеня серцево-судинного ризику;

- визначення пацієнтів із ризиком цукрового діабету 2 типу [1];

- проведення основних дій (питати, радити, оцінювати, допомагати, домовлятися) щодо тютюнокуріння;

- вміння консультувати пацієнтів із гіпертензією та цукровим діабетом щодо самодопомоги; 
- практичне використання інструменту «AUDIT» щодо ризиків, пов'язаних із вживанням алкоголю;

- розуміння та дотримання клінічних настанов, у тому числі критеріїв скерування пацієнтів із гіпертензією та цукровим діабетом до вузьких спеціалістів [1];

- надання коротких порад щодо харчування та фрізичної активності;

- використання мотиваційного консультування для поведінкових змін;

- оволодіння навичками для якісної взаємодії та консультування;

- розуміння основних принципів з оптимізації організаційного процесу в наданні послуг із профрілактики, своєчасної діагностики та ведення пацієнтів із гіпертензією та цукровим діабетом;

- впровадження базових принципів для вдосконалення якості діяльності медичної установи;

- визначення пацієнтів із високим ризиком гіпертензії чи цукрового діабету, які потребують первинної та вторинної медичної допомоги, відповідно до уніфрікованих клінічних протоколів та міжнародних клінічних настанов $[1,7]$.

У ході тренінгу відбувається ознайомлення учасників із реєстром медико-технологічних документів, що включає 79 наказів МО3 України, якими затверджено: 93 адаптованих клінічних настанови, рекомендовані як джерела найкращої клінічної практики; 5 стандартів медичної допомоги; 123 уніфікованих клінічних протоколи медичної допомоги; 22 протоколи медичної сестри (фельдшера, акушерки); 36 протоколів провізора (фрармацевта).

Із числа найважливіших нормативно-правових документів МОЗ України, які розглядають на тренінгу, $є$ «Зміни до Методики розробки та впровадження медичних стандартів (уніфікованих клінічних протоколів) медичної допомоги на засадах доказової медицини» [4], у які входять питання розробки клінічних маршрутів на підставі міжнародних клінічних настанов без адаптації, зміни до методики розробки системи індикаторів якості медичної допомоги та перелік джерел клінічних настанов; «Про затвердження Порядку надання первинної медичної допомоги», що включає завдання, зміст і вимоги щодо організації та забезпечення надання первинної медичної допомоги, перелік послуг із ПМД та організацію їх надання.

Перший етап для забезпечення навчання фрахівців ПМД Волинської області за курсом «нтегроване ведення випадків гіпертензії та діабету» визначення потенційного контингенту фрахівців первинної ланки медичної допомоги області, які могли б отримати специфічні знання щодо інтегрованого ведення пацієнтів із гіпертензією та цукровим діабетом; а також пошук шляхів, які найефективніше дозволили б організувати отримання таких знань.
Встановлено, що у Волинській області працює понад 500 сімейних лікарів та понад 750 медичних сестер сімейної медицини у державних і приватних закладах. Післядипломне навчання ці сімейні лікарі проходять переважно на базі кафедри сімейної медицини фракультету післядипломної освіти Львівського національного медичного університету імені Данила Галицького. Основними шляхами підвищення кваліфікації $€$ навчання на циклах спеціалізації, передатестаційних циклах та циклах тематичного удосконалення. Натомість післядипломне навчання медичних сестер сімейної медицини проводять на базі Луцького базового медичного коледжу. Відтак, є потреба у залученні викладачів закладів вищої медичної освіти IV та I-II рівнів акредитації, які здійснюють підготовку фахівців ПМД.

Другим етапом роботи було здійснення «ознайомчих» візитів до Волинської області у липні 2019 р. для обговорення організаційних питань. Участь в них брали працівники Бюро ВООЗ в Україні, Департаменту охорони здоров'я Волинської області, центрів громадського здоров'я, практикуючі сімейні лікарі, а також викладачі кафредр Львівського національного медичного університету імені Данила Галицького та Луцького базового медичного коледжу.

До порядку денного візитів вносили інформацію про основні втручання із НІ3 (WHO-PEN) для ПМД та організацію післядипломного навчання у 2019 p.

За результатами робочих зустрічей визначено обласну команду, до складу якої увійшли обласний координатор та тренери; терміни та шляхи підготовки тренерів та проведення тренінгів для працівників ПМД у Волинській області.

Окрім того, досягнуто домовленості щодо проведення у вересні 2019 р. тренінгу для тренерів. Проводитимуть його фахівці, які розробляли цей навчальний курс та є національними тренерами. Від Волинської області участь у навчанні візьмуть відібрані фрахівці, які після проходження навчання зможуть проводити тренінги для своїх колег у Волинській області.

Третім етапом роботи буде проведення дводенних тренінгів та моніторинг впровадження отриманих знань у практичну практику. Очікують, що персонал ПМД застосовуватиме нові підходи щодо запобігання, зменшення ризику та контролю за НІ3.

\section{Висновки}

1. Для забезпечення існування висококваліфрікованої та якісної медичної допомоги необхідна наявність достатньої кількості професіоналів, навчених її надавати. Ключову роль у системі профрілактики НI3 (зокрема гіпертензії та цукрового діабету) відіграють працівники, які працюють на первинній ланці медичної допомоги. Якщо вони 
пройдуть якісну підготовку з вищезазначених питань, існує реальна можливість того, що це матиме позитивний вплив на результати їхньої роботи 3 профрілактики НІ3 у пацієнтів.

2. Дводенний навчальний курс «Інтегроване ведення випадків гіпертензії та діабету» розроблено національною групою експертів за технічної підтримки ВООЗ і запропоновано для подальшої імплементації в Україні. Цей курс є оптимальним для підготовки фрахівців ПМД.

3. Викладачі Львівського національного медичного університету імені Данила Галицького і Луцького базового медичного коледжу, які здобувають кваліфріковані знання та сертифікати тренера 3 питань інтегрованого управління гіпертензією та цукровим діабетом, у подальшому використовуватимуть власні навички для навчання фахівців ПМД Волинської області. Водночас заплановано запровадити розроблені дистанційні курси 3 питань НI3, за успішне проходження яких сімейні лікарі зможуть отримувати бали безперервного профресійного розвитку.

Перспективи подальших досліджень. Перспективним $€$ охоплення даним навчанням усіх медичних фрахівців (лікарів та медичних сестер) на всіх рівнях щодо питань боротьби з НІ3 та їх профрілактики.

\section{Список літератури}

1. Джерела клінічних настанов [Електронний ресурс]. - Режим доступу : https://moz.gov.ua/article/protocols/test3.

2. Довідники Центру медичної статистики МОЗ України [Електронний ресурс]. - Режим доступу : http://medstat.gov. ua/ukr/statdov.html.

3. Дослідження Національної академії медичних наук України [Електронний ресурс]. - Режим доступу : http://amnu. gov.ua/category/naukova-diyalnist/doslidzhennya/.

4. Зміни до Методики розробки та впровадження медичних стандартів (унісрікованих клінічних протоколів) медичної допомоги на засадах доказової медицини : наказ МОЗ України від 29.12.2016 р. № 1422 [Електронний ресурс]. Режим доступу : https://zakon.rada.gov.ua/laws/show/z0530-17.

5. Лехан В. М. Інтегральна оцінка результатів діяльності системи охорони здоров'я України / В. М. Лехан, Л. В. Крячкова // Україна. Здоров'я нації. - 2010. - № 2 (14). - С. 53-65.

6. Неінфекційні захворювання: профілактика та зміцнення здоров'я в Україні : спільний проект МОЗ України та ВОО3 [Електронний ресурс]. - Режим доступу : https://moz.gov.ua/article/news/rozpochali-pershij-etap-spilnogo-zbjuro-vooz-proektu-schodo-profilaktiki-neinfekcijnih-zahvorjuvan-

7. Нові клінічні протоколи [Електронний ресурс]. - Режим доступу : https://guidelines.moz.gov.ua/.

8. Пакет важливих неіноекційних втручань хвороб (BOОЗ-PEN) для ПМД [Електронний ресурс]. - Режим доступу : https://www.youtube.com/watch?v=OSwYAlz3deUhttps://www.youtube.com/watch?v=OSwYAlz3deU.

9. Перетворення нашого світу: порядок денний у соері сталого розвитку до 2030 року : документ затверджений Самітом ООН зі сталого розвитку, вересень 2015 [Електронний ресурс]. - Режим доступу : http://sdg.org.ua/ua/sdgsand-governments.

10. Поліпшення охорони здоров'я на службі у людей : спільний проект Світового Банку (Міжнародного банку реконструкції та розвитку) та Міністерства охорони здоров'я України [Електронний ресурс]. - Режим доступу : https://wb.moz.gov.ua/pro-proekt.html.

\section{References}

1. Dzherela klinichnykh nastanov [Sources of clinical guidelines]. Retrieved from: https://moz.gov.ua/article/protocols/test3 [in Ukrainian].

2. Dovidnyky Tsentru medychnoi statystyky MOZ Ukrainy [Directories of the Health Statistics Center of the Ministry of Health of Ukraine]. Retrieved from: http://medstat.gov.ua/ukr/statdov.html [in Ukrainian].

3. Doslidzhennia Natsionalnoi akademii medychnykh nauk Ukrainy [Research of the National Academy of Medical Sciences of Ukraine]. Retrieved from: http://amnu.gov.ua/category/naukova-diyalnist/doslidzhennya/ [in Ukrainian].

4. Zminy do Metodyky rozrobky ta vprovadzhennia medychnykh standartiv (unifikovanykh klinichnykh protokoliv) medychnoi dopomohy na zasadakh dokazovoi medytsyny. Nakaz MOZ Ukrainy vid 29.12.2016 № 1422 [Changes to the Methodology of development and implementation of medical standards (unified clinical protocols) of medical care based on evidencebased medicine. Ministry of Health of Ukraine Order No. 1422 of 29.12.2016]. Retrieved from: https://zakon.rada.gov.ua/ laws/show/z0530-17 [in Ukrainian].

5. Lekhan, V.M., \& Kriachkova, L.V. (2010). Intehralna otsinka rezultativ diialnosti systemy okhorony zdorovia Ukrainy [Integral evaluation of the results of the health care system in Ukraine]. Zdorovia natsii - The Nation's Health, 2 (14), 53-65 [in Ukrainian].

6. Neinfektsiini zakhvoriuvannia: profilaktyka ta zmitsnennia zdorovia v Ukraini. Spilnyy proekt MOZ Ukrainy ta VOOZ [Non-communicable diseases: prevention and promotion of health in Ukraine. Joint project of the Ministry of Health of Ukraine and WHO]. Retrieved from: https://moz.gov.ua/article/news/rozpochali-pershij-etap-spilnogo-z-bjuro-voozproektu-schodo-profilaktiki-neinfekcijnih-zahvorjuvan- [in Ukrainian].

7. Novi klinichni protokoly [New clinical protocols]. Retrieved from: https://guidelines.moz.gov.ua/ [in Ukrainian]. 
8. Paket vazhlyvykh neinfektsiinykh vtruchan khvorob (VOOZ-PEN) dlia PMD [Package of important non-communicable disease interventions (WHO-PEN) for $\mathrm{PMH}$ ]. Retrieved from: https://www.youtube.com/watch?v=OSwYAlz3deUhttps:// www.youtube.com/watch?v=OSwYAlz3deU [in Ukrainian].

9. Peretvorennia nashoho svitu: poriadok dennyi u sferi staloho rozvytku do 2030 roku. Dokument zatverdzhenyi Samitom OON zi staloho rozvytku, veresen 2015 [Transforming our world: a 2030 agenda for sustainable development. Document approved by the United Nations Summit on Sustainable Development, September 2015]. Retrieved from: http://sdg.org.ua/ ua/sdgs-and-governments [in Ukrainian].

10. Polipshennia okhorony zdorovia na sluzhbi u liudei. Spilnyi proekt Svitovoho Banku (Mizhnarodnoho banku rekonstruktsiyi ta rozvytku) ta Ministerstva okhorony zdorovia Ukrainy [Improving public health at work. Joint project of the World Bank (International Bank for Reconstruction and Development) and the Ministry of Health of Ukraine]. Retrieved from: https://wb.moz.gov.ua/pro-proekt.html [in Ukrainian].

\section{ВНЕДРЕНИЕ В ПРОЦЕСС ОБУЧЕНИЯ СПЕЦИАЛИСТОВ ПЕРВИЧНОГО ЗВЕНА МЕДИЦИНСКОЙ ПОМОЩИ ВОЛЫНСКОЙ ОБЛАСТИ СОВРЕМЕННЫХ ЗНАНИЙ ПО ИНТЕГРИРОВАННОМУ ВЕДЕ- НИЮ СЛУЧАЕВ ГИПЕРТЕНЗИИ И САХАРНОГО ДИАБЕТА}

О. Е. Сичкориз ${ }^{1}$, Т. Г. Гутор ${ }^{1}$, О. Р. Ковальская ${ }^{1}$, К. П. РЫмаренко ${ }^{2}$

${ }^{1}$ Львовский национальный медицинский университет имени Данила Галицкого, г. Львов, Украина

Центр общественного здоровья МЗ Украины, г. Киев, Украина

Цель: проанализировать возможности организации обучения специалистов первичной медицинской помощи Волынской области по вопросам профилактики неинфекционных заболеваний (НИЗ) и интегрированного ведения пациентов с гипертензией и сахарным диабетом.

Материалы и методы. В работе использован комплекс специфических методов исследований социальной медицины, а также научной педагогики: системного подхода и системного анализа, медикостатистический, моделирования, организационного эксперимента, контент-анализа, инструментальный, эмпирический, учебно-дидактический и научного познания.

Результаты. Двухдневный учебный курс «Интегрированное ведение случаев гипертензии и диабета» был разработан национальной группой экспертов при технической поддержке ВОЗ и предложен для дальнейшей имплементации в Украине. Данный курс является оптимальным для подготовки специалистов первичной медицинской помощи.

Методики тренинга включают интерактивные лекции, практические занятия, рассмотрение клинических случаев и отработки практических навыков. Обязательным является оценка занятий, тренеров, тренинга в целом. К учебно-методическим материалам входят мультимедийные презентации лекций, раздаточные материалы для каждого участника тренинга.

В то же время запланировано ввести разработаные дистанционные курсы по НИЗ, за успешное прохождение которых семейные врачи смогут получать баллы непрерывного профессионального развития.

Выводы. Для обеспечения существования высококвалифицированной и качественной медицинской помощи необходимо наличие достаточного количества профессионалов, обученных ее предоставлять. Ключевая роль в системе профилактики НИЗ (в частности гипертензии и сахарного диабета) принадлежит работникам, работающим на первичном звене медицинской помощи. Если они пройдут качественную подготовку по вышеуказанным вопросам, существует реальная возможность того, что это окажет положительное влияние на результаты их работы по профилактике НИЗ у пациентов.

КЛЮЧЕВЫЕ СЛОВА: неинфекционные заболевания; артериальная гипертензия; сахарный диабет; тренинг; ВОЗ.

\section{INTRODUCTION OF MODERN KNOWLEDGE ON INTEGRATED CASE MANAGEMENT OF HYPERTENSION AND DIABETES INTO THE PROCESS OF PROFESSIONAL TRAINING OF PRIMARY CARE SPECIALISTS OF THE VOLYN REGION}

O. Ye. Sichkoriz' ${ }^{1}$, T. H. Gutor ${ }^{1}$, O. R. Kovalska ${ }^{1}$, K. P. Rymarenko ${ }^{2}$

${ }^{1}$ Danylo Halytskyi Lviv National Medical University, Lviv, Ukraine

${ }^{2}$ Public Health Center of $\mathrm{MOH}$ of Ukraine, Kyiv, Ukraine

Purpose: analysis of means and training organization of primary care specialists of the Volyn region on the prevention of NCDs and integrated management of patients with hypertension and diabetes.

Materials and Methods. The study involves a complex of specific methods of social medicine research, as well as scientific pedagogy: systemic approach and systemic analysis, medical-statistical, modeling, organizational experiment, content analysis, instrumental, empirical, educational-didactic and scientific knowledge.

Results. A two-day training course 'Integrated Management of Hypertension and Diabetes was developed by a national expert panel with WHO's technical support and proposed for further implementation in Ukraine. This course is optimal for training primary care specialists. 
Methods of the training include interactive lectures, workshops, clinical cases study and practical skills. It is mandatory to evaluate the classes, coaches, and training as a whole. Educational materials include multimedia lecture presentations, handouts for each training participant.

At the same time, there are plans to introduce the developed online training courses on NCDs, for the successful completion of which family doctors will be able to earn points of continuous professional development.

Conclusions. In order to ensure the availability of highly qualified and high quality medical care, it is necessary to have enough professionals trained to provide it. A key role in the prevention of NCDs (particularly, hypertension and diabetes) is played by primary care workers. If they receive quality training on the above issues, there is a real possibility that will have a positive impact on the outcomes of NCDs prevention for their patients.

KEY WORDS: non-communicable diseases; arterial hypertension; diabetes mellitus; training; WHO.

Рукопис надійшов до редакції 04.09.2019 p.

\section{Відомості про авторів:}

Січкоріз Орест Євгенович - кандидат медичних наук, доцент, декан фракультету післядипломної освіти Львівського національного медичного університету імені Данила Галицького; тел.: +38(032) 276-93-74.

Гутор Тарас Григорович - кандидат медичних наук, доцент, завідувач кафедри соціальної медицини, економіки та організації охорони здоров'я Львівського національного медичного університету імені Данила Галицького; тел.: +38(032) 276-81-67.

Ковальська Оксана Романівна - кандидат медичних наук, асистент кафедри соціальної медицини, економіки та організації охорони здоров'я Львівського національного медичного університету імені Данила Галицького; тел.: +38(032) 276-81-67.

Римаренко Катерина Павлівна - керівник відділу з профрілактики споживання тютюну та алкоголю Центру громадського здоров'я МОЗ України; тел.: +38(044) 294-64-97. 